\title{
FAKE CERTIFICATION TAGS OUTLAWED IN OREGON
}

\author{
E. R. Jackman, Extension Specialist in Farm Crops
}

I have noticed a good deal of alarm by correspondents from other states in regard to the practice of some firms using tags which look like certified seed tags. This will not be a problem in Oregon.

We have here a compulsory potato grading law which makes it necessary for all potatoes to be sold on grade. As part of this law appear the following clauses:

"Section 3. All potatoes sold or offered for sale or shipment in the state of Oregon shall conform to the United States or Oregon grades for potatoes provided however that potatoes that have been passed as "Standard" seed or "Certified" seed by and in conformity with the published standards, rules and regulations as they now are, or may be amended by the potato certification board of the Oregon Agricultural College, are exempt from further inspection."

"Section 6. All "Certified" or "standard" seed potatoes sold or offered for sale or shipment in the state of Oregon shall bear in addition to the label heretofore required, the official tag or seal of the potato certification board of the Oregon Agricultural College or if certified in another state the official tag or seal of the certifving agent of that state; provided that no potatoes may be sold as certified seed potatoes in the state of Oregon unless they have passed the certification requirements of the Oregon Agricultural College, or if certified in another state unless they have been passed by the official certifying agent of that state using standards found by such certification board to be at least equal in all respects to those of the Oregon Agricultural college."

The law further provides a penalty of a fine of from ten dollars to one hundred dollars or imprisonmment for ten to thirty days or both for violations. There was no difficulty in securing the passage of this law as it was evident that potato growers wanted it.

The "Standard" seed referred to above is a second class of seed allowing up to fijteen percent of mild mosaic and slightly more stem end discoloration. It is recommended for commercial growers as our supply of certified seed is very light. The new "Standard" seed promises to enjoy a splendid demand from sections interested only in providing table stock. It sold last spring for five dollars to ten dollars per ton over the price of seed of unknown origin.

\section{HAMLIN COUNTY SEED TREATMENT SURVEY}

George H. Valentine, Brookings, S. D.

During November a farm and home survey was conducted in eastern Hamlin County, South Dakota. The original purpose 